\title{
Assessment of volatile organic compounds from banana Terra subjected to different alcoholic fermentation processes
}

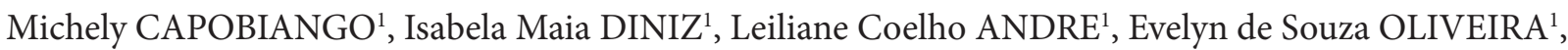 \\ Zenilda de Lourdes CARDEAL ${ }^{2 *}$
}

\begin{abstract}
Banana characteristics could provide yeast growth and support the action of yeast to produce beverages. The effects of enzymatic treatment, centrifugation, commercial yeast and two selected strains of Saccharomyces cerevisiae were investigated using the fermented banana Terra. Volatile organic compounds (VOCs) were determined by solid phase microextraction using gas chromatography mass spectrometry. The results showed that the condition employing enzymatic treatment, centrifugation and wet commercial yeast provided maximum ethanol yield (86\%) and effiency (98\%). Twenty-two compounds of distinct chemical classes were analysed including alcohols, esters, acids and aldehydes. The concentrations of the VOCs differed depending on the fermentation condition and were more influenced by using different yeasts. The limits of detection and quantification ranged from 0.056 to $2.694 \mathrm{mg} \mathrm{L}^{-1}$ and 0.057 to $2.904 \mathrm{mg} \mathrm{L}^{-1}$ respectively. Among the most prevalent VOCs the higher alcohols ranged from 353 to $1017 \mathrm{mg}$ per $100 \mathrm{~mL}$ of anhydrous alcohol. The fermented banana studied showed a composition similar to other fermented fruit pulps.
\end{abstract}

Keywords: fermented banana; volatile composition; GC/MS; SPME.

Practical Application: The manuscript provides a framework reports the first study on the kinetic parameters of alcoholic fermentation effects of different fermented banana Terra, and illustrates a SPME-GC/MS method applied to the analyses of volatile organic compounds profile. The results of this study show that the concentrations of the volatile compounds differed, depending on the fermentation condition. This work shows the importance of process standardization for alcoholic beverage.

\section{Introduction}

Banana is a tropical fruit widely consumed throughout the world. It has a rich aromatic flavour, nutritional value and a high concentration of sugar. The variety Terra (Musa AAB, Plantain subgroup) is one of the most popular banana varieties consumed in Brazil, Africa, the Caribbean and Latin America. Although bananas are widely produced and consumed, post-production loss represents a significant cost to the economy, and could result in waste of as much as half the crop (Aurore et al., 2009; Food and Agriculture Organization of the United Nations, 2011). In this context, alternative products for banana have been proposed, that would provide new resources, innovative products and minimize crop waste. The banana, in the last stage of maturation, presents high fermentable sugar content and does not have commercial value; although, it still presents nutritional value and aromatic quality. So this raw material can be used in the production of fermented and spirit beverages and is considered in this study (Alvarenga et al., 2011; Aurore et al., 2009).

Alcohol beverages are highly complex mixtures of compounds, in addition to ethanol, including a series of volatile organic compounds (VOCs). These compounds define the aroma, appearance and taste properties of these beverages (Cardeal \& Marriott, 2009; Morakul et al., 2012; Nonato et al., 2001). Different factors influence the composition and concentration levels of VOCs, such as raw materials, fermentation parameters, yeast strain and/or the distillation process, as well as aging (Ferreira et al., 1996; Nonato et al., 2001). Additionally, standardization of the production process is absent and is generally carried out subjectively. As a result, there may be variations in ethanol yield and productivity, yeast efficiency, and organoleptic characteristics of the beverage.

For these reasons, the aim of this study was to evaluate the influence of enzymatic treatment, centrifugation and yeast strains on the alcohol fermentation of banana Terra by kinetic parameters and VOCs profile. The impacts of these factors were evaluated according to the following kinetic parameters: ethanol yield, productivity and yeast efficiency. Furthermore, the volatile composition of different fermented banana was analysed using solid phase microextraction (SPME) with gas chromatography mass spectrometry (GC/MS).

${ }^{1}$ Department of Food Science, Faculdade de Farmácia, Universidade Federal de Minas Gerais - UFMG, Belo Horizonte, MG, Brazil

${ }^{2}$ Department of Chemistry, Instituto de Ciências Exatas - ICEx, Universidade Federal de Minas Gerais - UFMG, Belo Horizonte, MG, Brazil

*Corresponding author: zenilda@ufmg.br 


\section{Materials and methods}

\subsection{Samples, yeast strain and reagents}

Banana Terra (Musa sapientum) in the last stage of maturation was purchased from local markets in Belo Horizonte (Brazil). The pulp was obtained by mashing the bananas and the total soluble solids were adjusted to $15^{\circ}$ Brix (Association of Official Analytical Chemists, 2000a). The must was frozen and stored for future use. The effect of freezing banana must was evaluated and findings revealed that it has no impact on ethanol yield (Capobiango et al., 2012).

Itaiquara brand Saccharomyces cerevisiae (Minas Gerais, Brazil) was used as the wet commercial yeast (WCY), which was used before in others fermentation process (Alvarenga et al., 2011), and Fleischmann brand (Sorocaba, Brazil) as the dry commercial yeast (DCY) to compare with the wet strain. All were purchased from a local market in Belo Horizonte (Brazil). After optimization of the fermentation conditions two selected yeast strains (S. cerevisiae), UFMGA-1007 and UFMGA-1031, were obtained from the Laboratory of Ecology and Microbiology at UFMG which were originally isolated at a sugarcane spirits distillery in Minas Gerais (Brazil) because of their high performance on the sugarcane fermentation process (Silva et al., 2009).

The reagents were purchased from different suppliers: ethanol (J.T. Baker, Mexico) 1-propanol, 2-methyl-1-propanol, 3-methyl-1-butanol (Vetec, Brazil), ethyl acetate, acetic acid, hexanol, lactate ethyl (Fluka, Germany), hexanoic acid (Aldrich, Germany) and ultrapure water from a Milli-Q purification system (Millipore, Milford, Massachusetts).

\subsection{Effects of different variables on alcoholic fermentation}

A $2^{3}$ two-level full factorial design was used in the investigation of the effects of the independent variables; enzymatic treatment, centrifugation and commercial yeast on the alcoholic fermentation of banana: HCD - Hydrolyzed, centrifuged and dry yeast; NHCD - Non-hydrolyzed, centrifuged, and dry yeast; HNCD - Hydrolyzed, non-centrifuged and dry yeast; NHNCD - Non-hydrolyzed, non-centrifuged and dry yeast; HCW - Hydrolyzed, centrifuged and wet yeast; NHCW - Non-hydrolyzed, centrifuged and wet yeast; HNCW - Hydrolyzed, non-centrifuged and wet yeast; NHNCW - Non-hydrolyzed, non-centrifuged and wet yeast. The optimum conditions, of theses eight, involved an enzymatic hydrolysis and centrifugation and the commercial wet yeast.

The enzymatic treatment was performed using pectinolytic enzymes Pectinex Ultra SP (Novozymes, São Paulo, Brazil) at $0.025 \%(\mathrm{v} / \mathrm{w})$ at $30^{\circ} \mathrm{C}$ for $78 \mathrm{~min}$. Banana must was centrifuged at $4000 \mathrm{rpm}$ (Model T23, Janetzki, Germany) for $10 \mathrm{~min}$ in order to obtain the banana juice. The commercial yeast was suspended in sterile water at $30^{\circ} \mathrm{C}$ at $20 \mathrm{~g} \mathrm{~L}^{-1}$ to initiate fermentation. The yeast viability was previously analysed in a Neubauer chamber (Oliveira et al., 2005).

\subsection{Employing selected yeast}

The optimized fermentation condition was applied to test the selected yeast and the banana must was inoculated with the suspension cells of strains, UFMGA-1007 and UFMGA-1031. Cells were suspended in sterile water to provide the same concentration before undertaking the fermentation tests.

\subsection{Fermentation conditions}

Inoculation was done by addition of a cell suspension of yeast corresponding a $10 \%$ of the volume of must adjusted previously, yielding a concentration of $8 \times 10^{9}$ cells $\mathrm{mL}^{-1}$. Fermentation was conducted using Erlenmeyer flasks containing $100.000 \mathrm{~g}$ of must, and covered with cotton plugs. The must was incubated under static conditions at a controlled temperature at $30 \pm 1{ }^{\circ} \mathrm{C}$ until the release of $\mathrm{CO}_{2}$ was less than $0.099 \mathrm{~g}$ for each flask.

\subsection{Kinetic parameters of fermentation}

The kinetic parameters of fermentation were calculated as a function of the ethanol yield (\%) and productivity $\left(\mathrm{g} \mathrm{L}^{-1} \mathrm{~h}^{-1}\right)$, and the efficiency of the yeast (\%). In order to calculate these parameters, total reducing sugars (TRS), density, $\mathrm{pH}$, and total titrable acidity (TTA) of the banana and fermented musts were determined (Supplementary Table). The ethanol content in the fermented must also was measured. TRS was determined according Miller (1959). The ${ }^{\circ}$ Brix and TTA were measured following Association of Official Analytical Chemists (2000a, b) methods, respectively. The $\mathrm{pH}$ was measured using a $\mathrm{pH}$ meter (QUIMIS, São Paulo, Brazil). The ethanol content was determined following Zimmermann (1963) using a microstill (Te-012 Tecnal, São Paulo, Brazil).

The ethanol yield (\%) was calculated using the following Equation 1:

Ethanol yield $(\%)=\frac{\text { Ethanol produced }}{\text { Theoretical quantify }} \times 100$

The fermentation efficiency (\%) was calculated using the following Equation 2:

Efficiency $(\%)=\frac{\text { Ethanol produced }}{(\text { TRSmust }- \text { TRSfermentedmust }) \times 0.511} \times 100$

The productivity $\left(\mathrm{g} \mathrm{L}^{-1} \mathrm{~h}^{-1}\right)$ was expresses by the Equation 3 .

Productivity $=\frac{\text { Ethanol produced }(g)}{\text { Fermented must Volume }(L) x \operatorname{Time}(h)}$

\subsection{Analysis of volatile compounds}

The SPME method for VOCs extraction was performed using a polyacrylate (PA) $85 \mu \mathrm{m}$ fibre (Supelco, Bellefonte, PA, USA). The sample $(10.0 \mathrm{~mL})$ was added to $22 \mathrm{~mL}$ Pyrex vials containing $0.5 \mathrm{~g}$ of sodium chloride and the vials were immediately sealed. The fibre was inserted into the headspace for $25 \mathrm{~min}$ at $60^{\circ} \mathrm{C}$. Subsequently, the fibre was introduced into the GC injector to allow thermal desorption of the analytes at $240^{\circ} \mathrm{C}$ for $3 \mathrm{~min}$, in splitless mode (Nonato et al., 2001). For analysis of the blank, 
the same procedure was performed using the matrix with 5\% ethanol without standard.

A mixture of $n$-alkanes, $\mathrm{C}_{9}-\mathrm{C}_{22}$, at $40 \mathrm{mg} \mathrm{L}^{-1}$ in hexane (Sigma-Aldrich, St. Louis, MO) was injected to calculated linear retention indices. The calibration curve was prepared in six-point concentrations according to Eurachem guidelines (Cooperation on International Traceability in Analytical Chemistry, 2002) in the range of 10.0 to $340.0 \mathrm{mg} \mathrm{L}^{-1}$ of 1-propanol, 9.6 to $240.6 \mathrm{mg}$ $\mathrm{L}^{-1}$ of 2-methyl-1-propanol, 99.9 to $999.9 \mathrm{mg} \mathrm{L}^{-1}$ of 3-methyl1-butanol, 11.0 to $121.0 \mathrm{mg} \mathrm{L}^{-1}$ of hexanol, 3.4 to $56.3 \mathrm{mg} \mathrm{L}^{-1}$ of ethyl acetate, 1.0 to $103.4 \mathrm{mg} \mathrm{L}^{-1}$ of ethyl lactate, 11.6 to 127.9 $\mathrm{mg} \mathrm{L}^{-1}$ of hexanoic acid.

The VOCs analysis was carried out using an Agilent 7890A gas chromatograph coupled to an Agilent 5975C quadrupole mass spectrometer (Agilent Technologies, Wilmington, DE, USA) with a VOCOL capillary column $(60 \mathrm{~m} \times 0.25 \mathrm{~mm} \times 0.15 \mu \mathrm{m})$ (Supelco, Bellefonte, PA, USA). The oven temperature was set at $70^{\circ} \mathrm{C}$ for $2 \mathrm{~min}$, raised to $150^{\circ} \mathrm{C}$ at $5^{\circ} \mathrm{C} \mathrm{min}-1$, then to $180^{\circ} \mathrm{C}$ at $10^{\circ} \mathrm{C} \mathrm{min}{ }^{-1}$ and maintained for $20 \mathrm{~min}$. The carrier gas used was helium at a flow rate of $0.66 \mathrm{~mL} \mathrm{~min}^{-1}$. Data were acquired in electron-impact mode (EI) at $70 \mathrm{eV}$ using full scan mode (mass range: $30-550 \mathrm{~m} / z$ ). The collection of data was performed using ChemStation E.02021431 software (Agilent Technologies, Wilmington, DE, USA).

\subsection{Statistical analysis}

All steps were carried out in triplicate. One-way analysis of variance (ANOVA) and Tukey's test were applied to the experimental data. The Pareto Chart was applied to check for interactive effects among the variables using the Statistica 8.0 software (Statsoft Inc., Tulsa, OK, USA). The experimental data were compiled to generate a final matrix of 10 samples (fermentations conditions) and 7 variables (concentrations of each VOCs). The significance level was 0.05 .

The parameters of merit were evaluated according to Eurachem guidelines (Cooperation on International Traceability in Analytical Chemistry, 2002). To evaluate the linearity of the curve, the following statistical tests were applied: normality of residues (Ryan-Joiner Test), independence of residues (DurbinWatson Test), homoscedasticity of residues (Brown-Forsythe Test), significance regression, and deviation from linearity based on ANOVA test (de Souza \& Junqueira, 2005).

\section{Results and discussion}

\subsection{Effect of enzymatic treatment, centrifugation and commercial yeast strains}

The amounts of ethanol produced in banana fermented musts were significantly different and ranged from $1.9 \%$ to $6.4 \%(\mathrm{v} / \mathrm{v})$ (Table 1).

These values were comparable among different varieties of banana and fruit wines (Alvarenga et al., 2011; González et al., 2010). The independent variables significantly influenced the kinetic parameters. The results showed that the use of banana must submitted to enzymatic treatment, centrifugation and WCY provided maximum ethanol yield (86\%) and efficiency
Table 1. Kinetic parameters for alcoholic fermentation of banana Terra musts*.

\begin{tabular}{lccccc}
\hline Experiments $^{\mathrm{a}}$ & $\begin{array}{c}\text { Ethanol } \\
\left(\mathrm{g} 100 \mathrm{~m} \mathrm{~L}^{-1}\right)\end{array}$ & $\begin{array}{c}\text { Ethanol } \\
\text { Yield } \\
(\%)^{\#}\end{array}$ & $\begin{array}{c}\text { Efficiency } \\
(\%)^{\#}\end{array}$ & $\begin{array}{c}\text { Productivity } \\
\left(\mathrm{g} \mathrm{L}^{-1} \mathrm{~h}^{-1}\right)^{\#}\end{array}$ \\
\hline 1 & $\mathrm{HCD}$ & $2.4 \pm 0.1$ & $33.0 \pm 0.2^{\mathrm{e}}$ & $94 \pm 2^{\mathrm{bc}}$ & $1.00 \pm 0.01^{\mathrm{e}}$ \\
2 & $\mathrm{NHCD}$ & $1.9 \pm 0.1$ & $25.0 \pm 0.1^{\mathrm{f}}$ & $96 \pm 1^{\mathrm{ab}}$ & $0.80 \pm 0.01^{\mathrm{f}}$ \\
3 & $\mathrm{HNCD}$ & $2.7 \pm 0.1$ & $36.0 \pm 0.1^{\mathrm{d}}$ & $89 \pm 1^{\mathrm{d}}$ & $1.20 \pm 0.02^{\mathrm{d}}$ \\
4 & $\mathrm{NHNCD}$ & $1.9 \pm 0.1$ & $23.0 \pm 0.1^{\mathrm{f}}$ & $74 \pm 1^{\mathrm{g}}$ & $0.80 \pm 0.01^{\mathrm{f}}$ \\
5 & $\mathrm{HCW}$ & $6.2 \pm 0.2$ & $86.0 \pm 0.1^{\mathrm{a}}$ & $98 \pm 1^{\mathrm{a}}$ & $2.20 \pm 0.03^{\mathrm{c}}$ \\
6 & NHCW & $6.2 \pm 0.3$ & $83.0 \pm 0.4^{\mathrm{b}}$ & $89 \pm 1^{\mathrm{d}}$ & $2.30 \pm 0.01^{\mathrm{c}}$ \\
7 & $\mathrm{HNCW}$ & $6.4 \pm 0.2$ & $86 \pm 2^{\mathrm{a}}$ & $92 \pm 3^{\mathrm{cb}}$ & $2.70 \pm 0.07^{\mathrm{a}}$ \\
8 & NHNCW & $6.2 \pm 0.1$ & $78.0 \pm 0.4^{\mathrm{c}}$ & $81 \pm 1^{\mathrm{f}}$ & $2.40 \pm 0.01^{\mathrm{b}}$ \\
\hline
\end{tabular}

${ }^{*}$ Average $\pm \mathrm{SD}(n=3) .{ }^{*}$ Differentlettersin same column indicatesignificant differences $\left(\mathrm{p}=5.1^{-24}\right.$, $\mathrm{p}=1.1^{-12}, \mathrm{p}=2.1^{-23}$, respectively). ${ }^{a} \mathrm{HCD}-$ Hydrolyzed, centrifuged and dry yeast; $\mathrm{NHCD}$ - Non-hydrolyzed, centrifuged, and dry yeast; HNCD - Hydrolyzed, non-centrifuged and dry yeast; NHNCD - Non-hydrolyzed, non-centrifuged and dry yeast; HCW - Hydrolyzed, centrifuged and wet yeast; NHCW - Non-hydrolyzed, centrifuged and wet yeast; HNCW - Hydrolyzed, non-centrifuged and wet yeast; NHNCW Non-hydrolyzed, non-centrifuged and wet yeast.

(98\%). There was no significant difference between HCW and HNCW and they presented high ethanol yield. Therefore, in the industrial process, HNCW could be a better option than HCW since it reduces the beverage production process by one step. The productivity evaluates the rate of sugar converted to ethanol. All conditions of the experiments using WCY showed higher values for productivity. The Pareto Chart (Figure 1) shows the effects and interactions of the kinetic parameters.

All variables and interaction effects were significant for ethanol yield and productivity. The commercial yeast was negligible for efficiency; whereas the interaction between yeast and enzymatic treatment was significant. These results showed that the kinetic parameters were strongly influenced by the process of fermentation, mainly the enzymatic treatment and yeast strain.

The enzymatic treatment promotes pectin degradation, thus reducing the capacity of water retention. This water is then released into the system, thereby decreasing the viscosity (Jayani et al., 2005; Lee et al., 2006). Furthermore, centrifugation improves the fermentation process, making the must more fluid and supporting the performance of the yeast. Both variables positively affected alcoholic fermentation, which promoted the growth of yeast and increased the ethanol yield. The WCY presented higher ethanol yield and productivity than DCY. This may possibly be due to cell viability remaining at $96 \%$ and $87 \%$, respectively, despite having the same concentrations of inoculated cells. Also, the WCY requires less time (mean of 19 hours) to complete the alcoholic fermentation compared to DCY (mean of 22 hours). This result could be influenced by cell viability, stuck fermentation, reducing the capacity of the yeast to ferment the sugar into ethanol. However, no comparisons between wet and dry commercial yeasts have been reported in the literature, to date.

\subsection{Yeast strain selected}

The results of using selected strains UFMGA-1007 and UFMGA-1031 compared to WCY are presented in Table 2. 

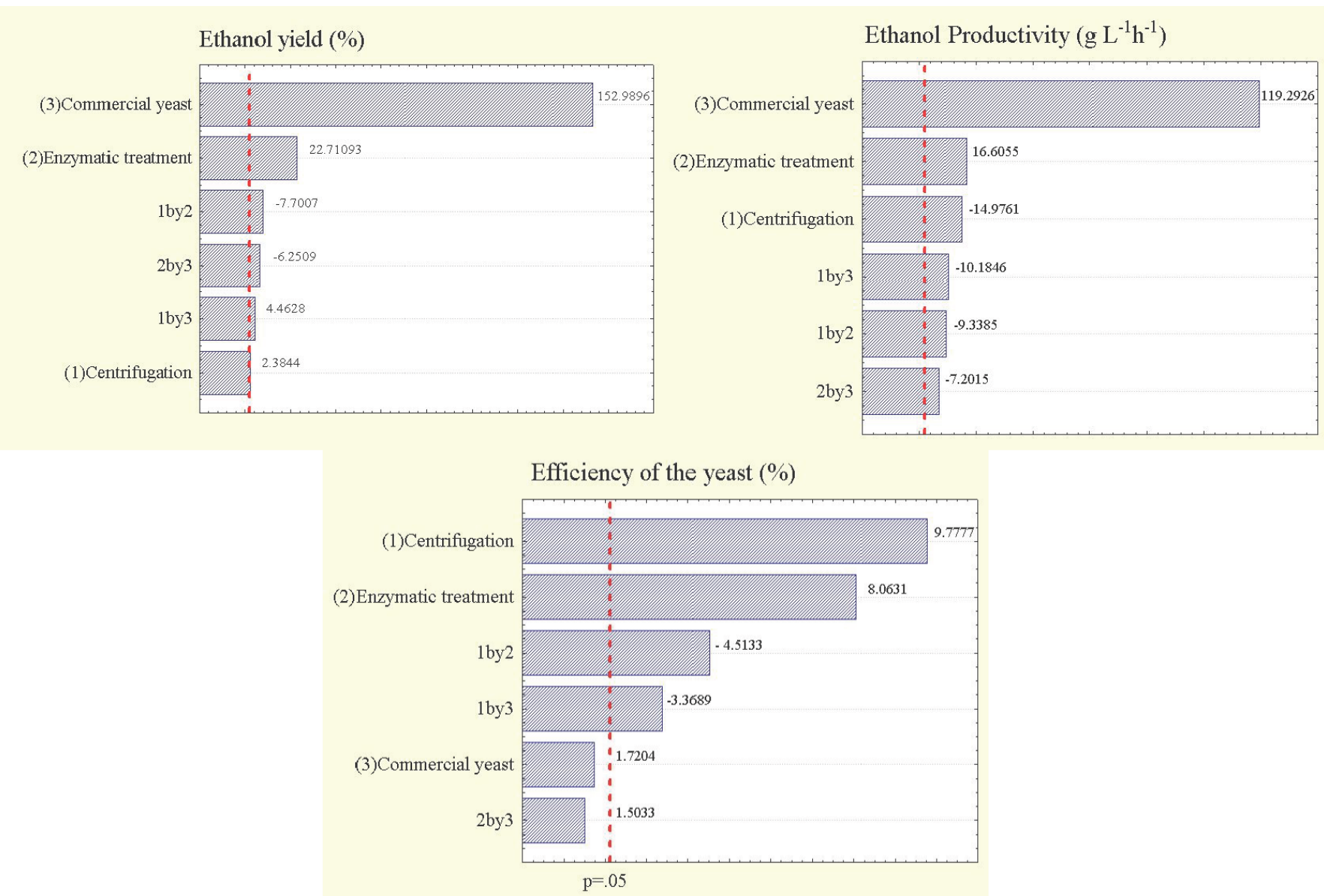

Figure 1. Pareto charts showing the effect of the variables in ethanol yield, efficiency of the yeast and productivity of alcoholic fermentation of banana must.

Table 2. Effect of selected yeast strain on the alcoholic fermentation of banana must*

\begin{tabular}{cccccc}
\hline Experiments & $\begin{array}{c}\text { Ethanol } \\
\left(\mathrm{g} 100 \mathrm{~mL}^{-1}\right)\end{array}$ & $\begin{array}{c}\text { Ethanol } \\
\text { Yield } \\
(\%)^{\#}\end{array}$ & $\begin{array}{c}\text { Efficiency } \\
(\%)^{*}\end{array}$ & $\begin{array}{c}\text { Productivity } \\
\left(\mathrm{g} \mathrm{L}^{-1} \mathrm{~h}^{-1}\right)^{*}\end{array}$ \\
\hline 5 & HCW & $6.2 \pm 0.2$ & $86 \pm 1^{\mathrm{a}}$ & $98 \pm 1^{\mathrm{a}}$ & $2.20 \pm 0.03^{\mathrm{c}}$ \\
9 & UFMGA-1007 & $2.9 \pm 0.3$ & $40 \pm 1^{\mathrm{c}}$ & $94 \pm 2^{\mathrm{c}}$ & $1.00 \pm 0.01^{\mathrm{c}}$ \\
10 & UFMGA-1031 & $3.1 \pm 0.4$ & $42 \pm 1^{\mathrm{b}}$ & $95 \pm 1^{\mathrm{b}}$ & $1.10 \pm 0.79^{\mathrm{b}}$ \\
\hline
\end{tabular}

${ }^{*}$ Average $\pm \mathrm{SD}(n=3)$. " Different letters in same column indicate significant differences $\left(\mathrm{p}=5.1^{-13}, \mathrm{p}=9.9^{-3}, \mathrm{p}=5.2^{-13}\right.$, respectively).

All kinetic parameters demonstrated significant difference and the commercial yeast presented the highest performance (ethanol yield $85.97 \%$; efficiency $97.98 \%$; productivity $2.24 \mathrm{~g} \mathrm{~L}^{-1} \mathrm{~h}^{-1}$ ).

The ethanol yields obtained with S. cerevisiae UFMGA-1007 and UFMGA-1031 were 40 and $42 \%$, respectively. Alvarenga et al. (2011) evaluated the effect of different selected yeast strains on the fermentation of the banana juice must, variety Nanica. The use of commercial yeast (96\%) also showed better results for ethanol yield than the selected strains (73 to $91 \%$ ).

Productivity also was higher with the WCY than the selected yeast. WCY requires less time (19 hours) than selected yeasts (mean of 25 hours) to complete the alcoholic fermentation and would benefit the industrial process in terms of efficiency of alcoholic fermentation of banana must.

The WCY showed better results than the selected strains. This could be explained by differences in yeast strain and yeast tolerance to the adaptation of must, even though the cell viability of UFMGA-1031 (91\%) and UFMGA-1007 (92\%) was similar to that of WCY. It might also be due to differences in experimental conditions of the alcoholic fermentation processes, such as an initially harsh environment and the different varieties of banana, and due of stuck fermentation. Maisonnave et al. (2013) related the specific sensitivity of yeast strains to the composition of the must. Therefore, the identification or types of cell strains in the commercial yeast need to be clarified.

\subsection{Analysis of volatile organic compounds by SPME CG/MS}

A total of 22 non-target VOCs were tentatively identified by library search and retention index. The chromatogram example was showed on Supplementary Figure. Among the most prevalent were alcohols, esters, acids, and aldehydes (Table 3). The VOCs were more influenced by using different yeasts than by manipulating other parameters. However, analysis of VOCs shows numerous differences in the intensities and concentrations of some compounds. 
Table 3. Volatile organic compounds analysed in different fermented banana Terra musts*.

\begin{tabular}{|c|c|c|c|c|c|c|c|c|c|c|c|c|}
\hline Compounds & $I_{\text {Literature }}^{a}$ & $I_{\text {Calculated }} \mathrm{b}$ & $\mathrm{HCD}$ & NHCD & NHCD & NHNCD & HCW & NHCW & HNCW & NHNCW & UFMGA-1007 & UFMGA-1031 \\
\hline 1-Propanol ${ }^{\mathrm{b}}$ & 627 & 604 & $\mathrm{x}$ & $\mathrm{x}$ & $\mathrm{x}$ & $\mathrm{x}$ & $\mathrm{x}$ & $\mathrm{x}$ & $\mathrm{x}$ & $\mathrm{x}$ & $\mathrm{x}$ & $\mathrm{x}$ \\
\hline Acetic Acid ${ }^{b}$ & 576 & 542 & $\mathrm{x}$ & $\mathrm{x}$ & $\mathrm{x}$ & $\mathrm{x}$ & $\mathrm{x}$ & $\mathrm{x}$ & $\mathrm{x}$ & $\mathrm{x}$ & $\mathrm{x}$ & $\mathrm{x}$ \\
\hline Acetaldehyde Hydroxyl & 706 & 659 & $\mathrm{x}$ & & $\mathrm{x}$ & & $\mathrm{x}$ & & & & $\mathrm{x}$ & $\mathrm{x}$ \\
\hline Ethyl Acetate $\mathrm{e}^{\mathrm{b}}$ & 628 & 672 & $\mathrm{x}$ & $\mathrm{x}$ & $\mathrm{x}$ & & $\mathrm{x}$ & $\mathrm{x}$ & $\mathrm{x}$ & $\mathrm{x}$ & $\mathrm{x}$ & $\mathrm{x}$ \\
\hline 2-Methyl-1-Propanol ${ }^{\mathrm{b}}$ & 660 & 682 & $\mathrm{x}$ & $\mathrm{x}$ & $\mathrm{x}$ & $\mathrm{x}$ & $\mathrm{x}$ & $\mathrm{x}$ & $\mathrm{x}$ & $\mathrm{x}$ & $\mathrm{x}$ & $\mathrm{x}$ \\
\hline Propanoic acid, 2-Methyl & 793 & 821 & $\mathrm{x}$ & $\mathrm{x}$ & $\mathrm{x}$ & $\mathrm{x}$ & $\mathrm{x}$ & $\mathrm{x}$ & $\mathrm{x}$ & $\mathrm{x}$ & & \\
\hline 3-Methyl-1-Butanol ${ }^{\mathrm{b}}$ & 844 & 828 & $\mathrm{x}$ & $\mathrm{x}$ & $\mathrm{x}$ & $\mathrm{x}$ & $\mathrm{x}$ & $\mathrm{x}$ & $\mathrm{x}$ & $\mathrm{x}$ & $\mathrm{x}$ & $\mathrm{x}$ \\
\hline 2-Methyl-1-Butanol & 852 & 834 & $\mathrm{x}$ & $\mathrm{x}$ & $\mathrm{x}$ & $\mathrm{x}$ & $\mathrm{x}$ & $\mathrm{x}$ & $\mathrm{x}$ & $\mathrm{x}$ & $\mathrm{x}$ & $\mathrm{x}$ \\
\hline 2,3-Butanediol & 897 & 924 & $\mathrm{x}$ & $\mathrm{x}$ & $\mathrm{x}$ & $\mathrm{x}$ & $\mathrm{x}$ & $\mathrm{x}$ & $\mathrm{x}$ & $\mathrm{x}$ & $\mathrm{x}$ & $\mathrm{x}$ \\
\hline 3-Methylbutanoic Acid & 971 & 953 & $\mathrm{x}$ & $\mathrm{x}$ & $\mathrm{x}$ & $\mathrm{x}$ & $\mathrm{x}$ & $\mathrm{x}$ & $\mathrm{x}$ & $\mathrm{x}$ & $\mathrm{x}$ & $\mathrm{x}$ \\
\hline $\begin{array}{l}\text { Ethyl (S)-2- } \\
\text { Hydroxypropanoate }^{\mathrm{b}}\end{array}$ & 993 & 970 & $\mathrm{x}$ & $\mathrm{x}$ & $\mathrm{x}$ & $\mathrm{x}$ & $\mathrm{x}$ & $\mathrm{x}$ & $\mathrm{x}$ & $\mathrm{x}$ & & $\mathrm{x}$ \\
\hline 1-Hexanol & 990 & 1044 & $\mathrm{x}$ & $\mathrm{x}$ & $\mathrm{x}$ & $\mathrm{x}$ & $\mathrm{x}$ & $\mathrm{x}$ & $\mathrm{x}$ & $\mathrm{x}$ & $\mathrm{x}$ & $\mathrm{x}$ \\
\hline $\begin{array}{l}\text { 2-Hydroxypropanoic } \\
\text { Acid }\end{array}$ & 1058 & 1035 & $\mathrm{x}$ & $\mathrm{x}$ & $\mathrm{x}$ & $\mathrm{x}$ & & & & $\mathrm{x}$ & $\mathrm{x}$ & $\mathrm{x}$ \\
\hline $\begin{array}{l}\text { 3-Methylbut-1-yl } \\
\text { Ethanoate }\end{array}$ & 1117 & 1054 & & & & & $\mathrm{x}$ & $\mathrm{x}$ & $\mathrm{x}$ & $\mathrm{x}$ & $\mathrm{x}$ & $\mathrm{x}$ \\
\hline 2,3-Dihydroxypropanal & 913 & 1062 & $\mathrm{x}$ & & $\mathrm{x}$ & $\mathrm{x}$ & $\mathrm{x}$ & & & & $\mathrm{x}$ & $\mathrm{x}$ \\
\hline Hexanoic Acid ${ }^{\mathrm{b}}$ & 1186 & 1194 & $\mathrm{x}$ & $\mathrm{x}$ & $\mathrm{x}$ & $\mathrm{x}$ & $\mathrm{x}$ & $\mathrm{x}$ & $\mathrm{x}$ & $\mathrm{x}$ & $\mathrm{x}$ & $\mathrm{x}$ \\
\hline Ethyl Hexanoate & 1229 & 1233 & $\mathrm{x}$ & $\mathrm{x}$ & $\mathrm{x}$ & $\mathrm{x}$ & $\mathrm{x}$ & $\mathrm{x}$ & $\mathrm{x}$ & $\mathrm{x}$ & $\mathrm{x}$ & $\mathrm{x}$ \\
\hline Propane-1,2,3-triol & 1196 & 1257 & $\mathrm{x}$ & $\mathrm{x}$ & $\mathrm{x}$ & $\mathrm{x}$ & $\mathrm{x}$ & $\mathrm{x}$ & $\mathrm{x}$ & $\mathrm{x}$ & $\mathrm{x}$ & $\mathrm{x}$ \\
\hline Octanoic Acid & 1370 & 1379 & $\mathrm{x}$ & $\mathrm{x}$ & $\mathrm{x}$ & $\mathrm{x}$ & $\mathrm{x}$ & $\mathrm{x}$ & $\mathrm{x}$ & $\mathrm{x}$ & $\mathrm{x}$ & $\mathrm{x}$ \\
\hline Phenylethyl Alcohol & 1272 & 1459 & $\mathrm{x}$ & $\mathrm{x}$ & $\mathrm{x}$ & $\mathrm{x}$ & $\mathrm{x}$ & $\mathrm{x}$ & $\mathrm{x}$ & $\mathrm{x}$ & $\mathrm{x}$ & $\mathrm{x}$ \\
\hline Ethyl Octanoate & 1436 & 1415 & $\mathrm{x}$ & $\mathrm{x}$ & $\mathrm{x}$ & $\mathrm{x}$ & $\mathrm{x}$ & $\mathrm{x}$ & $\mathrm{x}$ & $\mathrm{x}$ & $\mathrm{x}$ & $\mathrm{x}$ \\
\hline D-Glucose & 1698 & 1695 & $\mathrm{x}$ & $\mathrm{x}$ & $\mathrm{x}$ & $\mathrm{x}$ & $\mathrm{x}$ & $\mathrm{x}$ & $\mathrm{x}$ & $\mathrm{x}$ & $\mathrm{x}$ & $\mathrm{x}$ \\
\hline
\end{tabular}

${ }^{\star}$ Average \pm SD ( $\left.\mathrm{n}=3\right) .{ }^{\text {a }}$ Database Acree \& Arn (2014), El-Sayed (2012), National Institute of Standards and Technology (2009). ${ }^{\mathrm{b}}$ Retention index calculated using authentic standard of alkane series.

Seven higher alcohols were identified in fermented banana musts and several of them have already been found in banana fruit (Selli et al., 2012; Vermeir et al., 2009). In spirits, the sum of 1-propanol, 2-methyl-1-propanol and 3-methyl-1-butanol expresses the total concentration of higher alcohols. If these compounds are higher than $360 \mathrm{mg} 100 \mathrm{~mL}^{-1}$ of anhydrous alcohol (aa) it is an indication of poor beverage quality, due to their strong, pungent smell and taste (López-Vázquez et al., 2010). However, they may contribute to the floral nuance of alcoholic beverages when present in low concentrations (Duarte et al., 2010). Favorable keynotes to alcoholic beverages have been attributed to 2-methyl-1-propanol, 2-methyl-1-butanol, 3-methyl-1-butanol and 1-hexanol (González et al., 2010; López-Vázquez et al., 2010; Reddy \& Reddy, 2011). 1-Hexanol is partially a non-alcoholic fermentation product which contributes to a green, grassy and leafy odour affecting both the aroma and taste of the beverage (González et al., 2010; Selli et al., 2012).

Methanol is reportedly associated with harmful effects on health and its presence in distilled fruit spirits is strictly controlled. Methanol was not detected in the fermented banana analysed in this study, which was verified with a standard.

Volatile components belonging to the group of fatty acids such as 2-methylpropanoic, 3-methylbutanoic, octanoic, hexanoic and decanoic acids can contribute significantly to the aroma of wines and spirits. Therefore, their odour may be as strong as that of acetic acid and also could be associated with the odour descriptor "rancid" (Zhang et al., 2011). Some of these fatty acids (hexanoic, octanoic and 3-methylbutanoic acids) occur naturally in fruit, they may be formed during the fermentation as secondary products of the yeast metabolism, and they could inhibit the alcoholic fermentation (Duarte et al., 2010; Ivanova et al., 2012; Oliveira et al., 2011). All these compounds were detected in the fermented banana studied.

Different studies of the banana aroma profile indicate that the characteristic of banana maturity is determined by the presence of esters (Selli et al., 2012; Vermeir et al., 2009). Some esters, such as ethyl acetate, lactate, hexanoate, octanoate and 3-methylbut-1-yl ethanoate were detected in the fermented banana studied. Esters constitute one of the most interesting classes of aromatic VOCs, mainly ethyl esters, in alcoholic beverages such as mango wine (Reddy \& Reddy, 2011) and grape pomace spirits (López-Vázquez et al., 2010). Indeed, esters are associated with a pleasant aroma because of their fruity and floral notes (Duarte et al., 2010; Hernández-Gómez et al., 2003).

\subsection{Analytical validations and quantification of VOCs}

Table 4 reports the results of parameters of merit that were evaluated according to Eurachem guidelines (Cooperation on International Traceability in Analytical Chemistry, 2002). The tests performed showed that the residues followed a normal distribution, were independent and possessed homoscedasticity. ANOVA showed that the regression was significant and that there was no deviation from linearity. The limits of detection (LOD) and quantification (LOQ) were calculated according to the recommendations of the Eurachem Guidelines (Cooperation on International Traceability in Analytical Chemistry, 2002) through 
Table 4. Linearity $\left(\mathrm{R}^{2}\right)$ limits of detection (LOD) and quantification (LOQ) of the SPME-GC/MS method used for quantification of VOCs of fermented banana musts.

\begin{tabular}{|c|c|c|c|c|c|c|c|c|}
\hline \multirow{3}{*}{ Compounds ${ }^{\mathrm{a}}$} & \multirow{3}{*}{ Quantitation ions } & \multirow{3}{*}{$\begin{array}{c}\text { Linearity } \\
\left(\mathrm{R}^{2}\right)\end{array}$} & \multirow{3}{*}{$\begin{array}{c}\text { LOD } \\
\left(\mathrm{mg} \mathrm{L}^{-1}\right)\end{array}$} & \multirow{3}{*}{$\begin{array}{c}\text { LOQ } \\
\left(\mathrm{mg} \mathrm{L}^{-1}\right)\end{array}$} & \multicolumn{4}{|c|}{ Coefficients of Variation $^{\mathrm{a}}$} \\
\hline & & & & & \multicolumn{2}{|c|}{ intra-assay } & \multicolumn{2}{|c|}{ inter-assay } \\
\hline & & & & & $\mathrm{X} 2$ & $\mathrm{X} 5$ & $\mathrm{X} 2$ & $\mathrm{X} 5$ \\
\hline 1-propanol & 31 & 0.97216 & 2.694 & 2.721 & 16.28 & 12.11 & 18.13 & 11.55 \\
\hline 3-methyl-1-butanol & 55 & 0.99131 & 2.688 & 2.904 & 17.76 & 6.96 & 19.11 & 14.31 \\
\hline 1-hexanol & 56 & 0.99719 & 0.056 & 0.057 & 19.94 & 5.47 & 18.51 & 7.05 \\
\hline hexanoic acid & 60 & 0.98644 & 0.372 & 0.373 & 19.86 & 10.73 & 19.69 & 15.13 \\
\hline
\end{tabular}

${ }^{a}$ Concentration of second and fifth point of calibration curve.

the calibration curve using the equation $\mathrm{LOD}=$ mean of blank $+3 \mathrm{~S}$, and the $\mathrm{LOQ}=$ mean of blank $+10 \mathrm{~S}$, where $\mathrm{S}$ is the standard deviation for ten consecutive measurements of the blank. LOD and LOQ ranged from 0.056 to $2.694 \mathrm{mg} \mathrm{L}^{-1}$ and 0.057 to 2.904 $\mathrm{mg} \mathrm{L}^{-1}$ respectively. The intra- and inter-assay precision presents coefficients of variation less than $20 \%$, which is considered suitable for food analysis.

The validated method was applied to quantify seven compounds in fermented banana musts. The results, presented in Figure 2 as $\mathrm{mg}$ of compound per $100 \mathrm{~mL}$ of aa. The results showed that differences in the final amounts of some VOCs were statistically significant when employing the different fermentation conditions especially for the yeast employed: WCY, DCY and selected yeasts. These results could be attributed to differences in genetic material and variability in physiological properties of yeasts (Nyanga et al., 2013).

Principal component analysis was used to describe the correlation between samples fermentation conditions and the concentrations of the volatile organic compounds. Figure 3 shows the PCA scores plot (Figure 3a) and loadings plot (Figure 3b). The total variance explained by Factor 1 and 2 are $85.46 \%$. The results show that ethyl lactate, acetate, higher alcohols, 1-hexanol, hexanoic acid were the most contributions variables for the differentiation of fermentation conditions. Ethyl lactate and higher alcohols (1-propanol, 2-methyl-1propanol and 3-methyl-1-butanol) were directly related to condition 2 (NHCD), showing the higher concentrations of these compounds. Condition 4 (NHNCD) is related to production of higher contents of hexanol and hexanoic acid. The higher content of ethyl acetate was related to condition 7 ( $\mathrm{HNCW}$ ). Conditions closed to central point were not significant. The conditions 5 (HCW), close to zero, is concurring to kinetic parameters results showing best process to achieved higher ethanol yield.

In this work almost all fermented musts presented concentrations of higher alcohols above $360 \mathrm{mg}$ per $100 \mathrm{~mL}$ aa, except for the UFMGA-1007 (353.37 mg $100 \mathrm{~mL}^{-1}$ aa). Globally, the selected yeasts UFMGA-1007 and UFMGA-1031 produced lower content of higher alcohols, but showed lower ethanol yield. These were following by the group of WCY and DCY. The study by Duarte et al. (2010) on fermented fruits produced from the pulps of gabiroba, umbu, cupuassu, jaboticaba and cacao inoculated with S. cerevisiae UFLA CA 1162 revealed that higher alcohols are present in large concentrations in all fermented fruits

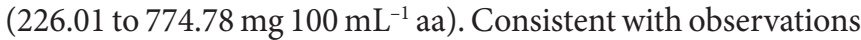
from this study, the amount of higher alcohols is dependent on the yeast strain and is responsible for the secondary aroma of beverages (Duarte et al., 2010; Nyanga et al., 2013).

1-Hexanol is considered to be favorable at concentrations between 0.5 to $10 \mathrm{mg} 100 \mathrm{~mL}^{-1}$ aa (González et al., 2010; Perestrelo et al., 2006). In this study, the concentration of 1-hexanol was lower using WCY (mean of $5.33 \mathrm{mg} 100 \mathrm{~mL}^{-1}$ aa) and it could be considered a positive characteristic for these samples.

The concentration of ethyl acetate varied among the fermented banana musts, independently of the fermentation conditions. The presences of acetate esters in low doses (50-80 $\left.\mathrm{mg} \mathrm{L}^{-1}\right)$ contribute to the aroma and have a positive impact on the quality of the product (Duarte et al., 2010; Hernández-Gómez et al., 2003). The average values found in the present study were in this range. This results are similar to other research using banana Nanica (32.84 mg $100 \mathrm{~mL}^{-1}$ aa) (Guimarães, 2003) and fruit such as gabiroba $\left(22.96 \mathrm{mg} 100 \mathrm{~mL}^{-1}\right.$ aa). However, different fruits provide different results. For example, the amount of ethyl acetate found in the present study was lower when using cacao (295.17 mg $100 \mathrm{~mL}^{-1}$ aa) which is consistent with other studies (Duarte et al., 2010). The results of the present study also showed that the VOCs in fermented banana musts were also found in other types of beverages made with different fruits.

The ethyl (S)-2-hydroxypropanoate, at low concentrations (10 mg $100 \mathrm{~mL}^{-1} \mathrm{aa}$ ), contributes to the stabilization of distillate flavour and softens the harsh flavour characteristics in beverages (Soufleros et al., 2005). This ester was detected at low concentrations in fermented banana musts (3.07 to $16.68 \mathrm{mg} 100 \mathrm{~mL}^{-1} \mathrm{aa}$ ) mainly when WCY was employed.

Although some volatile fatty acids are minor compounds in fruit spirits, their odour might have undesirable effects on the aroma when found in amounts above the thresholds $\left(0.7 \mathrm{mg} \mathrm{L}^{-1}\right)$ (Nyanga et al., 2013). Hexanoic acid was found at a concentration below the thresholds in the group employing WCY (2.7 mg 100 $\mathrm{mL}^{-1}$ aa). It was also described as being naturally present in raw banana fruit, in the range of 0.238 to $0.438 \mathrm{mg} \mathrm{Kg}^{-1}$ (Selli et al., 2012).

Oliveira et al. (2005) showed a negative correlation between the ethanol content and VOCs in sugarcane spirits, particularly in 
1-Propanol

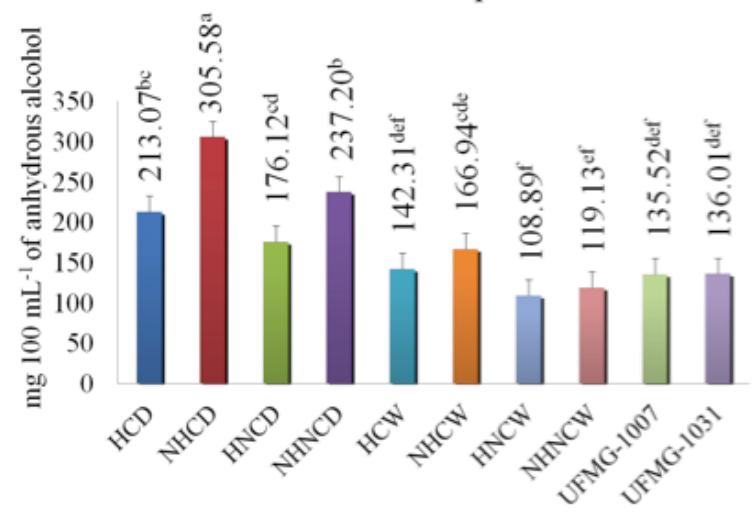

3-Methyl-1-Propanol

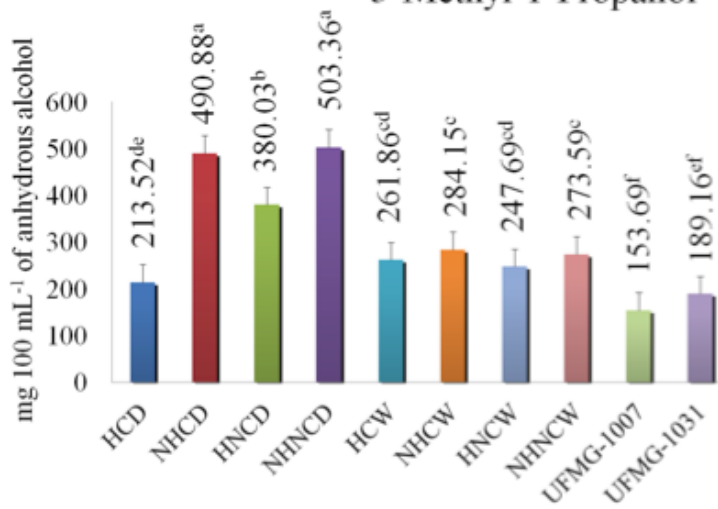

Ethyl acetate

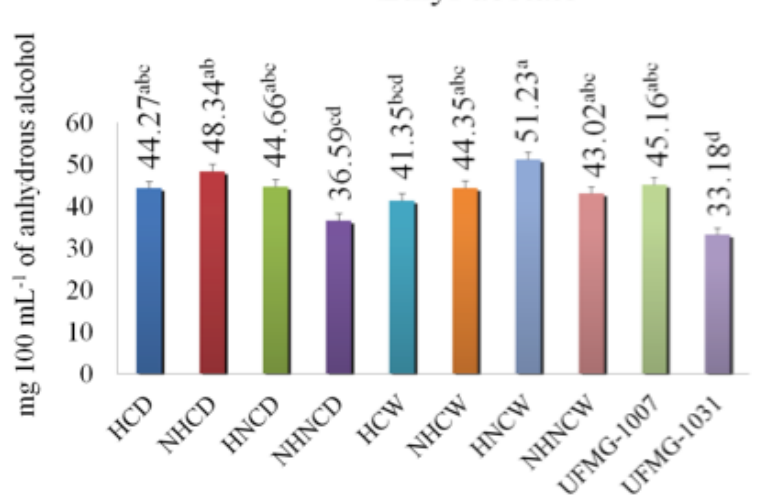

2-Methyl-1-Propanol

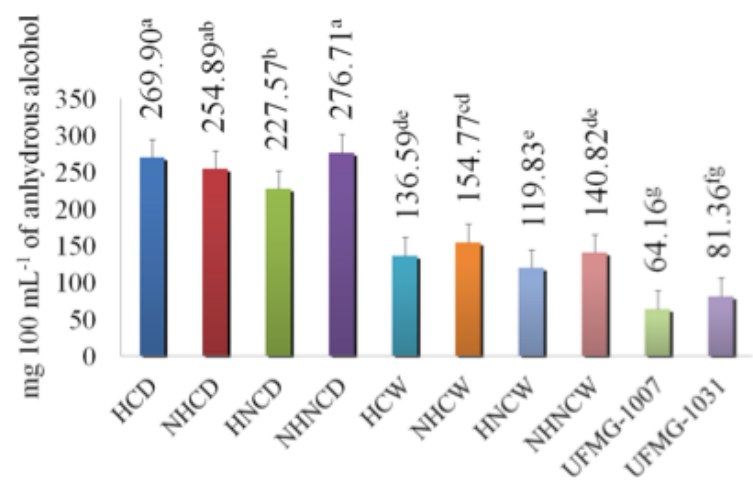

1-Hexanol

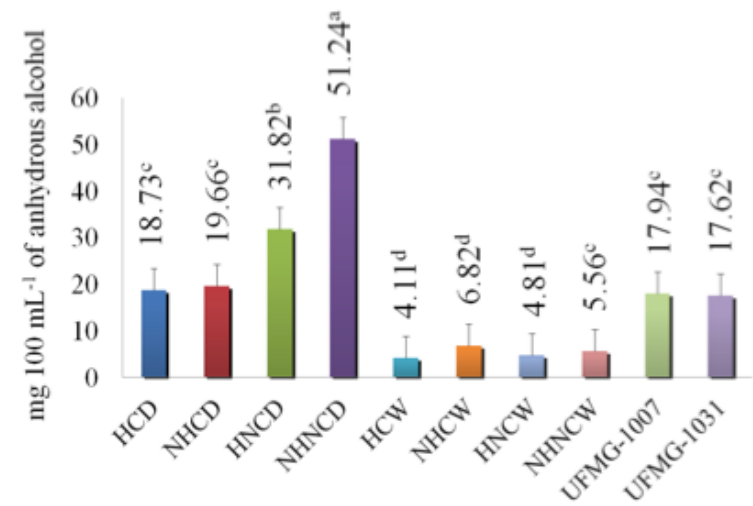

Ethyl lactate

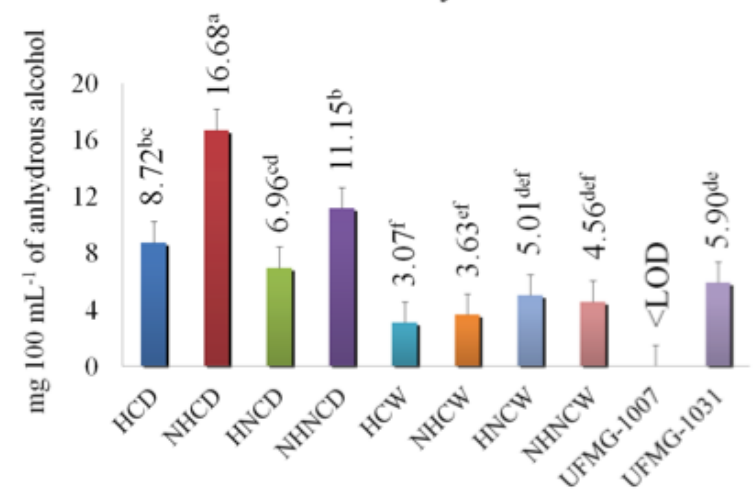

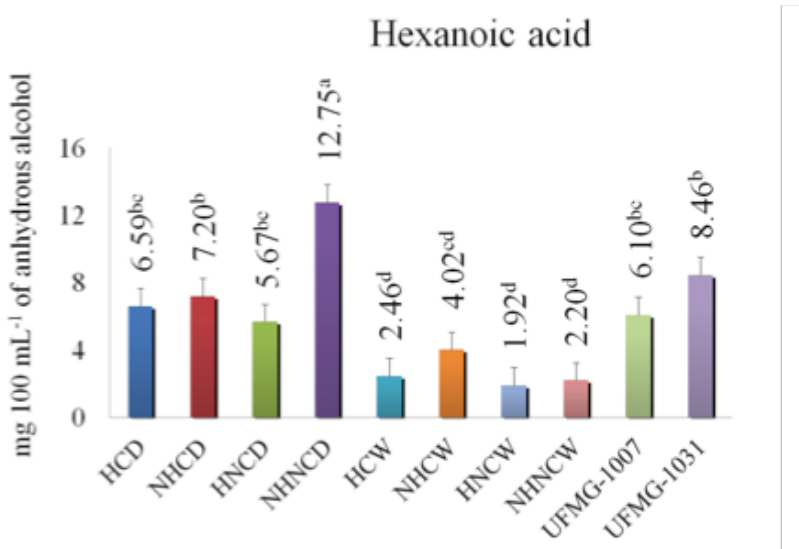

Figure 2. Volatile organic compounds concentration ( $\mathrm{mg} 100 \mathrm{~mL}^{-1}$ of anhydrous alcohol) in fermented banana musts, showing mean values and standard deviation bars. 


\section{Projection of the conditions on the factor-plane $(1 \times 2)(a)$}

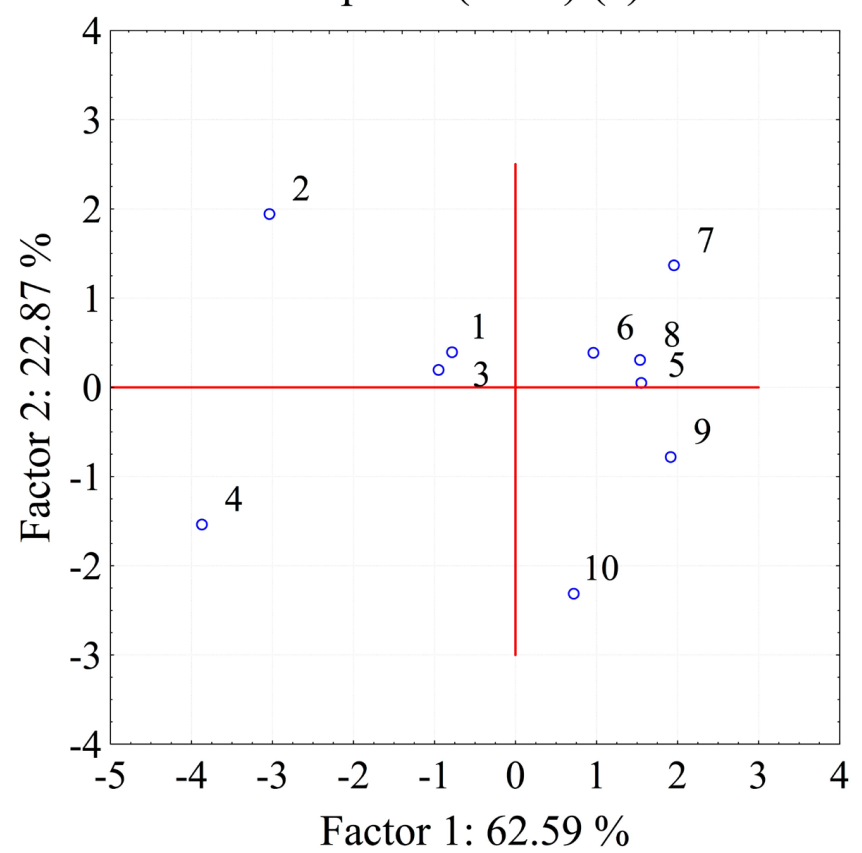

\section{Projection of the variables on the factor-plane (1 x 2) (b)}

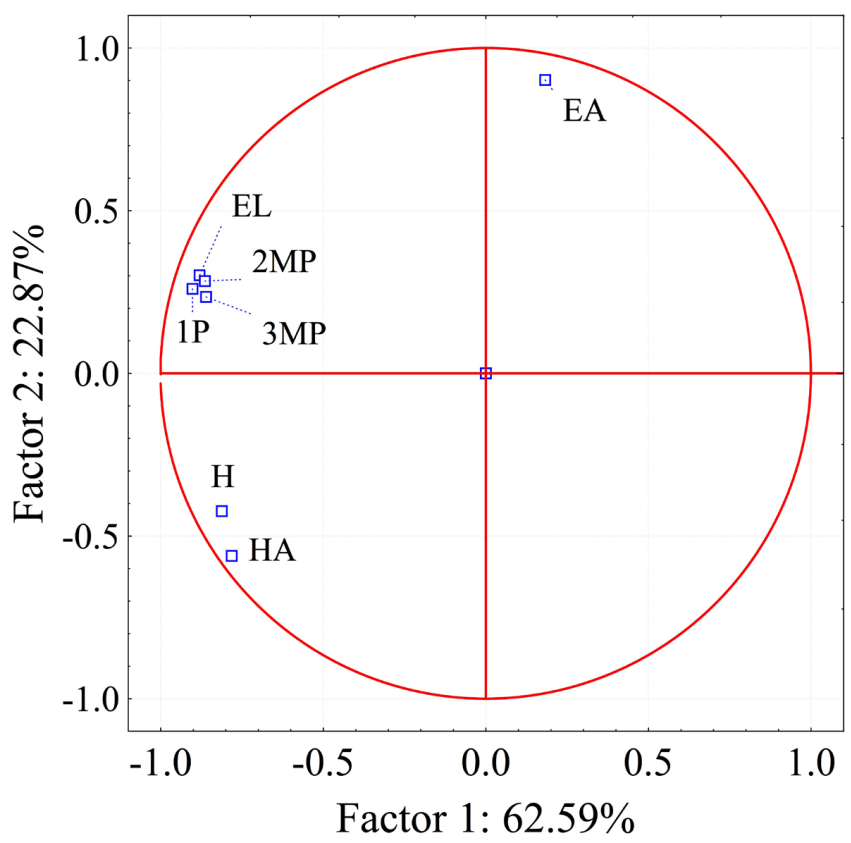

Figure 3. PCA scores plot (a) and loadings plot (b) to 10 different alcoholic fermented banana musts.

regard to acidity, ethyl acetate, 1-propanol, 2-methyl-1-propanol and 3-methyl-1-butanol. These correlations illustrate that a variation in the ethanol content of the fermented sugarcane must is an important factor for the standardization of the ethanol/volatiles ratio and the quality of the commercialized beverage produced in the industrial processes. In particular, clarifying the conditions of the fermentation processes will lead to improvements in the manufacturing of banana spirits with an acceptable amount of higher alcohols.

\section{Conclusions}

The present study shows that the kinetic parameters of alcoholic fermentation of banana Terra was influenced by yeast strain, enzymatic treatment and centrifugation. The maximum ethanol yield ( $85.97 \%$ and $86.39 \%$ ) and efficiency (97.98\%) were obtained using enzymatic treatment, WCY and centrifugation.

The SPME-GC/MS proved to be a useful, simple method that can be applied to evaluate aromatic compounds in beverages. A total of 22 VOCs were detected in fermented banana musts. The typical VOCs profile was determined especially by yeast strain and characteristics of the fermentation conditions. The PCA methodology was used to relate the presence of VOCs and fermentation conditions. The fermented banana Terra presented a volatile composition similar to that of other alcoholic beverages.

\section{Acknowledgements}

Funding for this study was provided by Fundação de Amparo a Pesquisa de Minas Gerais (FAPEMIG), Conselho Nacional de Pesquisa e Desenvolvimento (CNPq) and Coordenação de Aperfeiçoamento de Pessoal de Nível Superior-Brazil (CAPES).

\section{References}

Acree, T., \& Arn, H. (2014). Flavornet and human odor space. Geneva. Retrieved from http://flavornet.org

Alvarenga, R. M., Carrara, A. G., Silva, C. M., \& Oliveira, E. S. (2011). Potential application of Saccharomyces cerevisiae strains for the fermentation of banana pulp. African Journal of Biotechnology, 10(18), 3608-3615.

Association of Official Analytical Chemists - AOAC. (2000a). Official methods of analysis of the Association of Official Analytical Chemists: 932.12 Fruits and fruit products. Solids (Soluble) in fruits and fruit product: refractometer method (17th ed.). Virginia: AOAC.

Association of Official Analytical Chemists - AOAC. (2000b). Official methods of analysis of the Association of Official Analytical Chemists: 942.15A fruits and fruit products: acidity (Titratable) of fruit products (17th ed.). Virginia: AOAC.

Aurore, G., Parfait, B., \& Fahrasmane, L. (2009). Bananas, raw materials for making processed food products. Trends in Food Science \& Technology, 20(2), 78-91. http://dx.doi.org/10.1016/j.tifs.2008.10.003.

Capobiango, M., Diniz, I. M., Alvarenga, L. M., Cardeal, Z. L., \& Oliveira, E. S. (2012). Efeito do congelamento na fermentação alcóolica de polpa de banana. In XXIII Congresso Brasileiro de Ciência e Tecnologia de Alimentos, Campinas, Brazil.

Cardeal, Z. L., \& Marriott, P. J. (2009). Comprehensive two-dimensional gas chromatography: mass spectrometry analysis and comparison of volatile organic compounds in Brazilian cachaça and selected spirits. Food Chemistry, 112(3), 747-755. http://dx.doi.org/10.1016/j. foodchem.2008.06.057.

Cooperation on International Traceability in Analytical Chemistry - CITAC. EURACHEM. (2002). Guide to quality in analytical chemistry: an aid to accreditation. Leoben: EURACHEM. Retrieved 
from http://.eurachem.org/images/stories/Guides/pdf/CITAC_ EURACHEM_GUIDE.pdf

Duarte, W. F., Dias, D. R., Oliveira, J. M., Teixeira, J. A., Silva, J. B. A., \& Schwan, R. F. (2010). Characterization of different fruit wines made from cacao, cupuassu, gabiroba, jaboticaba and umbu. $L W T$ - Food Science and Technology, 43(10), 1564-1572. http://dx.doi. org/10.1016/j.lwt.2010.03.010.

El-Sayed, A. M. (2012). The pherobase: database of pheromones and semiochemicals. Retrieved from http://pherobase.com

Ferreira, V., Sharman, M., Cacho, J. F., \& Dennis, J. (1996). New and efficient microextraction solid-phase extraction method for the gas chromatographic analysis of wine volatiles. Journal of Chromatography. A, 731(1-2), 247-259. http://dx.doi.org/10.1016/0021-9673(95)01132-3.

Food and Agriculture Organization of the United Nations - FAO. (2011). Production crops: 2011. FAOSTAT. Retrieved from http:// faostat3.fao.org/home/index.html

González, E. A., Agrasar, A. T., Castro, L. M. P., Fernandez, I. O., \& Guerra, N. P. (2010). Production and characterization of distilled alcoholic beverages obtained by solid-state fermentation of black mulberry (Morus nigra L.) and black currant (Ribes nigrum L.). Journal of Agricultural and Food Chemistry, 58(4), 2529-2535. http:// dx.doi.org/10.1021/jf9037562. PMid:20102198.

Guimarães, O. Fo. (2003). Avaliação da produção artesanal da aguardente de banana utilizando Saccharomyces cerevisiae CA-1174. Lavras: Universidade Federal de Lavras.

Hernández-Gómez, L.F., Úbeda, J., \& Briones, A. (2003). Melon fruit distillates: comparison of different distillation methods. Food Chemistry, 82, 539-543. http://dx.doi.org/10.1016/S0308-8146(02)00512-5 10.1016/S0308-8146(03)00008-6.

Ivanova, V., Stefova, M., Vojnoski, B., Stafilov, T., Bíró, I., Bufa, A., Felinger, A., \& Kilár, F. (2012). Volatile composition of macedonian and hungarian wines assessed by GC/MS. Food and Bioprocess Technology, 6(6), 1609-1617. http://dx.doi.org/10.1007/s11947011-0760-y.

Jayani, R. S., Saxena, S., \& Gupta, R. (2005). Microbial pectinolytic enzymes: a review. Process Biochemistry (Amsterdam, Netherlands), 40(9), 2931-2944. http://dx.doi.org/10.1016/j.procbio.2005.03.026.

Lee, W. C., Yusof, S., Hamid, N. S. A., \& Baharin, B. S. (2006). Optimizing conditions for enzymatic clarification of banana juice using response surface methodology (RSM). Journal of Food Engineering, 73(1), 55-63. http://dx.doi.org/10.1016/j.jfoodeng.2005.01.005.

López-Vázquez, C., Herminia Bollaín, M., Berstsch, K., \& Orriols, I. (2010). Fast determination of principal volatile compounds in distilled spirits. Food Control, 21(11), 1436-1441. http://dx.doi. org/10.1016/j.foodcont.2010.03.008.

Maisonnave, P., Sanchez, I., Moine, V., Dequin, S., \& Galeote, V. (2013). Stuck fermentation: development of a synthetic stuck wine and study of a restart procedure. International Journal of Food Microbiology, 163(2-3), 239-247. http://dx.doi.org/10.1016/j.ijfoodmicro.2013.03.004. PMid:23584364.

Miller, G. L. (1959). Use of dinitrosalicylic acid reagent for determination of reducing sugar. Analytical Chemistry, 3(3), 426-428. http://dx.doi. org/10.1021/ac60147a030.

Morakul, S., Mouret, J. R., Nicolle, P., Aguera, E., Sablayrolles, J. M., \& Athès, V. (2012). A dynamic analysis of higher alcohol and ester release during winemaking fermentations. Food and Bioprocess Technology, 6(3), 818-827. http://dx.doi.org/10.1007/s11947-012-0827-4.

National Institute of Standards and Technology - NIST. (2009). Mass spectral search program (Version 2.0). Washington, D.C.: Secretary of Commerce of the United States of America.
Nonato, E. A., Carazza, F., Silva, F. C., Carvalho, C. R., \& Cardeal, Z L. (2001). A headspace solid-phase microextraction method for the determination of some secondary compounds of Brazilian sugar cane spirits by gas chromatography. Journal of Agricultural and Food Chemistry, 49(8), 3533-3539. http://dx.doi.org/10.1021/ jf000896r. PMid:11513624.

Nyanga, L. K., Nout, M. J., Smid, E. J., Boekhout, T., \& Zwietering, M. H. (2013). Fermentation characteristics of yeasts isolated from traditionally fermented masau (Ziziphus mauritiana) fruits. International Journal of Food Microbiology, 166(3), 426-432. http:// dx.doi.org/10.1016/j.ijfoodmicro.2013.08.003. PMid:24029027.

Oliveira, E. S., Cardello, H. M. A. B., Jeronimo, E. M., Souza, E. L. R., \& Serra, G. E. (2005). The influence of different yeasts on the fermentation, composition and sensory quality of cachaça. World Journal of Microbiology \& Biotechnology, 21(5), 707-715. http:// dx.doi.org/10.1007/s11274-004-4490-4.

Oliveira, M. E. S., Pantoja, L., Duarte, W. F., Collela, C. F., Valarelli, L. T., Schwan, R. F., \& Dias, D. R. (2011). Fruit wine produced from cagaita (Eugenia dysenterica DC) by both free and immobilised yeast cell fermentation. Food Research International, 44(7), 2391-2400. http://dx.doi.org/10.1016/j.foodres.2011.02.028.

Perestrelo, R., Fernandes, A., Albuquerque, F. F., Marques, J. C., \& Câmara, J. S. (2006). Analytical characterization of the aroma of Tinta Negra Mole red wine: Identification of the main odorants compounds. Analytica Chimica Acta, 563(1-2), 154-164. http:// dx.doi.org/10.1016/j.aca.2005.10.023. PMid:17386707.

Reddy, L. V. A., \& Reddy, O. V. S. (2011). Effect of fermentation conditions on yeast growth and volatile composition of wine produced from mango (Mangifera indica L.) fruit juice. Food and Bioproducts Processing, 89(4), 487-491. http://dx.doi.org/10.1016/j. fbp.2010.11.007.

Selli, S., Gubbuk, H., Kafkas, E., \& Gunes, E. (2012). Comparison of aroma compounds in Dwarf Cavendish banana (Musa spp. AAA) grown from open-field and protected cultivation area. Scientia Horticulturae, 141, 76-82. http://dx.doi.org/10.1016/j.scienta.2012.04.008.

Silva, C. L., Vianna, C. R., Cadete, R. M., Santos, R. O., Gomes, F. C., Oliveira, E. S., \& Rosa, C. A. (2009). Selection, growth, and chemo-sensory evaluation of flocculent starter culture strains of Saccharomyces cerevisiae in the large-scale production of traditional Brazilian cachaça. International Journal of Food Microbiology, 131(23), 203-210. http://dx.doi.org/10.1016/j.ijfoodmicro.2009.02.027. PMid:19329211.

Soufleros, E. H., Mygdalia, S. A., \& Natskoulis, P. (2005). Production process and characterization of the traditional Greek fruit distillate "Koumaro" by aromatic and mineral composition. Journal of Food Composition and Analysis, 18(7), 699-716. http://dx.doi.org/10.1016/j. jfca.2004.06.010.

Souza, S. V. C., \& Junqueira, R. G. (2005). A procedure to assess linearity by ordinary least squares method. Analytica Chimica Acta, 552(1-2), 25-35. http://dx.doi.org/10.1016/j.aca.2005.07.043.

Vermeir, S., Hertog, M. L. A. T. M., Vankerschaver, K., Swennen, R., Nicolaï, B. M., \& Lammertyn, J. (2009). Instrumental based flavour characterisation of banana fruit. LWT-Food Science and Technology, 42(10), 1647-1653. http://dx.doi.org/10.1016/j.lwt.2009.05.024.

Zhang, H., Woodams, E. E., \& Hang, Y. D. (2011). Influence of pectinase treatment on fruit spirits from apple mash, juice and pomace. Process Biochemistry (Amsterdam, Netherlands), 46(10), 1909-1913. http:// dx.doi.org/10.1016/j.procbio.2011.06.020.

Zimmermann, H. W. (1963). Studies on the dicromate method of alcohol determination. American Journal of Enology and Viticulture, $14,205-213$ 


\section{Supplementary data}

Supplementary Table. Mean values for the total reducing sugars (TRS), pH and acidity in the musts and fermented musts of banana Terra*.

\begin{tabular}{cccc}
\hline Experiments $^{\mathrm{a}}$ & $\begin{array}{c}\text { Total reducing sugars } \\
\left(\mathrm{g} \mathrm{L}^{-1}\right)\end{array}$ & $\mathrm{pH}$ & $\begin{array}{c}\text { Acidity } \\
\left(\mathrm{g} \text { of acetic acid } 100 \mathrm{~mL}^{-1}\right)\end{array}$ \\
\hline HCD & 74.6 & 4.21 & 0.46 \\
NHCD & 87.1 & 4.21 & 0.39 \\
HNCD & 69.1 & 4.16 & 0.46 \\
NHNCD & 83.8 & 4.25 & 0.39 \\
HCW & 13.7 & 4.06 & 0.54 \\
NHCW & 7.7 & 4.04 & 0.55 \\
HNCW & 7.3 & 4.03 & 0.57 \\
NHNCW & 5.5 & 4.05 & 0.54 \\
UFMGA-1007 & 65.2 & 4.09 & 0.41 \\
UFMGA-1031 & 62.8 & 4.07 & 0.45 \\
MHC & 124.6 & 4.28 & 0.34 \\
MNHC & 131.3 & 4.35 & 0.29 \\
MHNC & 130.1 & 4.21 & 0.36 \\
MNHNC & 135.4 & 4.45 & 0.33 \\
\hline
\end{tabular}

${ }^{a} \mathrm{HCD}$ - Hydrolyzed, centrifuged and dry yeast; NHCD - Non-hydrolyzed, centrifuged, and dry yeast; HNCD - Hydrolyzed, non-centrifuged and dry yeast; NHNCD - Non-hydrolyzed, non-centrifuged and dry yeast; HCW - Hydrolyzed, centrifuged and wet yeast; NHCW - Non-hydrolyzed, centrifuged and wet yeast; HNCW - Hydrolyzed, non-centrifuged and wet yeast; NHNCW - Non-hydrolyzed, non-centrifuged and wet yeast; MHC - Must hydrolyzed, centrifuged; MNHC - Must Non-hydrolyzed, centrifuged; MHNC - Must hydrolyzed, non-centrifuged; MNHNC - Must Non-hydrolyzed, non-centrifuged.

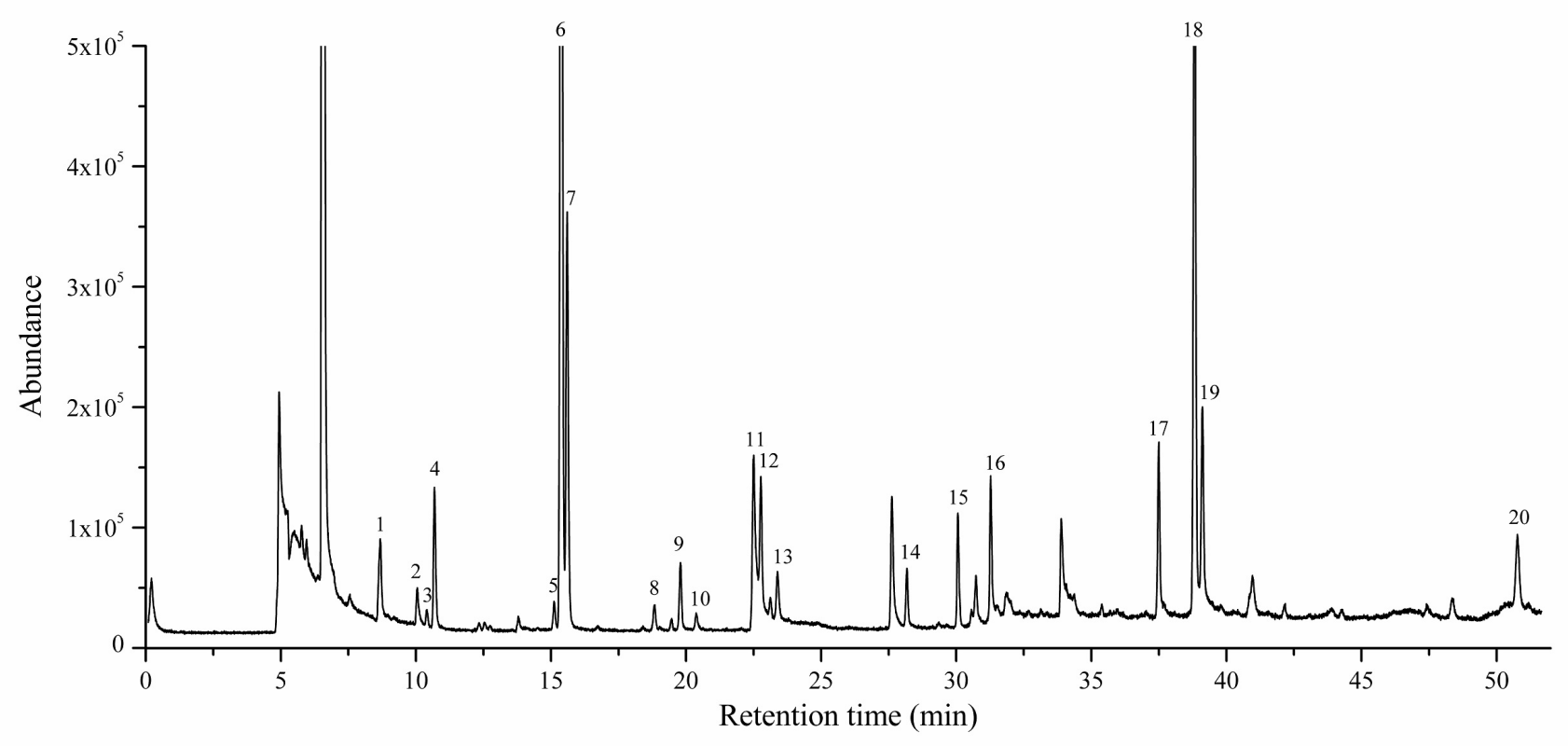

Supplementary Figure. Example of the Chromatogram of fermented banana must. (1)1-Propanol; (2)Acetic Acid (3)Ethyl Acetate; (4)2-Methyl-1-Propanol; (5)Propanoic acid, 2-Methyl; (6)3-Methyl-1-Butanol; (7)2-Methyl-1-Butanol; (8)2,3-Butanediol; (9)3-Methylbutanoic Acid; (10)Ethyl (S)-2-hydroxypropanoate; (11)2-Hydroxypropanoic Acid; (12)1-Hexanol; (13)2,3-Dihydroxypropanal; (14)Hexanoic Acid; (15)Ethyl Hexanoate; (16)Propane-1,2,3-triol; (17)Octanoic Acid; (18)Phenylethyl Alcohol; (19)Ethyl Octanoate; (20)D-Glucose. 